\title{
Look ahead
}

\section{A continued lack of coordination and a focus on short-term decision-making threaten to undermine long-term energy system ambitions intended to meet objectives in future decades.}

\begin{abstract}
The expansion of clean energy technologies throughout our power system seems to continue ever more rapidly these days. Wind power has now overtaken hydropower to become the largest source of renewable capacity in the US ${ }^{1}$. In the EU, $86 \%$ of new power capacity in 2016 came from renewable sources ${ }^{2}$, while wind power generated more electricity than coal in the $\mathrm{UK}^{3}$. February's announcement ${ }^{4}$ from Denmark's Dong Energy that it plans to cease its coal burning operations by 2023 also sent further signals that renewables are on the ascent. And yet the outlook remains far from rosy.

The recent energy outlooks to 2040 and 2035 from the International Energy Agency ${ }^{5}$ and $\mathrm{BP}^{6}$, respectively, show that while
\end{abstract} emissions are set to decline over time, they are not falling sufficiently fast to meet the ambitions of the Paris Agreement. The $2{ }^{\circ} \mathrm{C}$ target remains a long way off without deeper and more significant changes in global energy provision and consumption.

A study in this month's issue underlines this further. In their Article (article no. 17024), Steve Pye and colleagues examine the impact of $2{ }^{\circ} \mathrm{C}$ carbon budgets on the UK energy system, attempting to reach net-zero emissions before the end of the century as specified in the Paris Agreement. They find that current UK policy is unlikely to meet a net-zero target without greater mitigation efforts. Notably, they show that the time horizon over which policymakers consider system change must extend beyond midcentury if governments want to avoid missed objectives and surprises in the future.

Alongside this troubling absence of a longer-term view, the study also highlights that key uncertainties in the shorter term are being overlooked. These cover the spectrum from technical to economic and sociopolitical. If pledges aren't being considered on the right time scale and in light of appropriate uncertainty, the whole endeavour is at risk of failure almost before it's gotten started.

Two striking examples can be seen in the new Trump administration and recent Brexit developments. In the US, President Trump wasted no time in approving both the Keystone XL pipeline and the completion of the Dakota Access pipeline. He has also repealed transparency requirements that required oil and gas companies to disclose payments they make to foreign governments.
Both acts are in line with his America First Energy Plan (http://go.nature.com/213ChOZ), which advocates bringing back coal and fails to mention renewables - despite the fact that low carbon technologies account for $45 \%$ of employees in the electric power generation and fuels sector and the numbers of employees in the solar and wind workforces increased significantly in $2016^{7}$. These acts undermine the long-term energy system transition and increase the likely future need of even deeper, faster changes.

In the UK, the government's apparent commitment to nuclear power, exemplified by the greenlighting of Hinkley Point C, was brought into doubt by the Brexit-induced decision to withdraw from Euratom ${ }^{8}$, the European atomic power treaty. Expansion of nuclear power was intended to help the UK meet its climate objectives while maintaining sufficient generation capacity after its final coal-fired power stations close in 2025. The move to withdraw from Euratom has been criticised for creating uncertainty over how nuclear fuels and services - as well as safety inspections and non-proliferation commitments - can be easily supported in the UK in the future. If nuclear power is to remain a key component of future electricity supply in the UK, transitional arrangements and new treaties must be put in place as a matter of urgency. Further doubts have been cast by the government's call for new nuclear plants to provide prices that are 15-20\% lower than those agreed on for Hinkley ${ }^{9}$. Given the recent uncertainties around financing being faced by nuclear companies, it is getting harder to see how investors will be attracted to the UK unless there's a change in approach.

More widely, clearer thinking is called for in the transport sector. A recent study ${ }^{10}$ found that actual fuel consumption of new cars in Germany is $36 \%$ higher than shown in official reports. An earlier white paper ${ }^{11}$ found that the gap between real-world and manufacturer-approved emissions was $42 \%$ across European cars. The implications of this disparity for policies concerning climate and air quality targets are staggering. For consumers, this represents a further blow following the Volkswagen emissions scandal as they try to make choices in the face of rising fuel costs and levies on more polluting vehicles. The discrepancy also impacts on modelling and forecasting of fuel consumption in the transport sector, which could lead to underestimation of future energy needs and decarbonisation trajectories. New standards and frameworks for monitoring and assessment are urgently required to enable properly informed decisions about transport issues.

None of this is to say that the transition to a cleaner energy system is at risk. As also discussed in last month's Editorial ${ }^{12}$, the momentum is such that economic factors are increasingly adding impetus to the change. However, enacting the pledges of 2015 requires political will, foresight, and long-term oversight. Without stronger lines of thought between climate objectives, the energy system, and the social, economic, and political systems within which they exist, it will be increasingly difficult to translate the bold pledges on climate change into effective actions. A greater degree of coordination between the different sectors - both at national and international levels as well as between governments, academia, and industry - is essential if we're going to develop robust strategies and efficient feedback loops that can withstand the challenges to making decarbonisation a reality. Continuing silo-based thinking around decision-making and entertaining strategies filled only with rhetoric will simply kick the issue down the road. And by then it may be too late.

\footnotetext{
References

1. Near-record growth propels wind power into first place as America's largest renewable resource. American Wind Energy Association (9 February 2017); http://go.nature.com/2m7VX54

2. Wind in Power: 2016 European Statistics (WindEurope, 2017); http://go.nature.com/2kHFiZ1

3. Evans, S. UK wind generated more electricity than coal in 2016. Carbon Brief (5 January 2017); http://go.nature.com/2kHu86u

4. Clark, P. Dong aims to phase out coal-fired power generation by 2023. Financial Times (2 February 2017); http://go.nature. com/2mhQMyG

5. World Energy Outlook 2016 (OECD, IEA, 2016); http://go.nature com/213QFXd

6. BP Energy Outlook (BP, 2017); http://go.nature.com/2kUQDA

7. US Energy and Employment Report (US Department of Energy, 2017); http://go.nature.com/213JxtU

8. Vaughan, A. Brexit will delay new British nuclear power stations, warn experts. The Guardian (27 February 2017); http://go.nature. com/2lqVnzh

9. Ward, A. Demand for power price cuts puts UK nuclear plants viability in doubt. Financial Times (15 February 2017); http://go.nature.com/2lizR1m

10. Tietge, U., Mock, P., Franco, V. \& Zacharof, N. Energy Policy 103, 212-222 (2017).

11. From Laboratory to Road: a 2016 Update of Official and 'RealWorld' Fuel Consumption and $\mathrm{CO}_{2}$ Values for Passenger Cars In Europe (International Council on Clean Transportation, 2016) http://go.nature.com/2lCzpvh

12. Nat. Energy 2, 17017 (2017).
} 